\title{
Effects of in vitro triacontanol on growth, antioxidant enzymes, and photosynthetic characteristics in Arachis hypogaea L.
}

\author{
Aman Verma $^{1 *}$, Chander Parkash Malik ${ }^{1}$, Vijay Kumar Gupta ${ }^{2}$ and Bhavneet Kaur Bajaj ${ }^{3}$ \\ ${ }^{1}$ School of Life Sciences, Jaipur National University, Jaipur-302025, India \\ ${ }^{2}$ Department of Biochemistry, Kurukshetra University, Kurukshetra, India \\ ${ }^{3}$ DuPont Agricultural Biotechnology, Plant Protection, Wilmington, DE - 19880, USA \\ *Corresponding author: email: verma.aman1980@gmail.com Fax number: 0141-2452626 \\ Received: 14 February 2011; Accepted: 24 January 2012
}

\section{ABSTRACT:}

In vitro effects of triacontanol (TRIA) on antioxidant enzymes and photosynthetic characteristics were studied in Arachis hypogaea L. cultivars (M-13 and PBS24030). The in vitro impact of TRIA on multiplication potential was also evaluated, which was found to be best at $2.0 \mathrm{ml} \mathrm{L}^{-1}$ TRIA in combination with 6- Benzyl adenine (BA, $3 \mathrm{mg} \mathrm{L}^{-1}$ ) in both the groundnut cultivars. Rhizogenesis was observed in almost all the TRIA treated cultures in both the cultivars. Moreover, shoots failed to set roots, in the presence of BA. Total chlorophyll content, total soluble sugars, total soluble proteins and ascorbate peroxidase (APX; EC 1.11.1.11) activity were found to be increasing with increasing concentrations of TRIA, whether alone or in combination with $B A$, however, genotypic differences were observed in case of Hill reaction activity (HRA) in between the cultivars. Best catalase (CAT; EC 1.11.1.6) activity was reported at $1.0 \mathrm{ml} \mathrm{L}^{-1}$ TRIA with BA (3 $\left.\mathrm{mg} \mathrm{L}^{-1}\right)$ in both the cultivars. Peroxidase (POX; EC 1.11.1.7) and polyphenol oxidase (PPX; 1.14.18.1) activity was maximum at $1.0 \mathrm{ml} \mathrm{L}^{-1}$ TRIA with $B A\left(3 \mathrm{mg} \mathrm{L}^{-1}\right)$ in $\mathrm{M}-13$, whereas at $2.0 \mathrm{ml} \mathrm{L}^{-1}$ TRIA with BA $\left(3 \mathrm{mg} \mathrm{L}^{-1}\right)$ in PBS24030. Lipid peroxidation was found to be reduced with the supplementation of TRIA. The results obtained in the study clearly indicated not only the in vitro establishment of groundnut cultivars in the presence of TRIA but also its effect on various growth promontory physiological parameters.

Key words: Catalase, Groundnut, Peroxidase, Vipul

\section{INTRODUCTION}

Peanut (Arachis hypogaea L.) or groundnut is grown in tropical and warmer temperate regions throughout the world. The crop provides an excellent source of protein and other nutrients. Seeds contain about $50 \%$ oil (Cheng et al., 1992), $22-30 \%$ proteins on a dry basis, a rich source of minerals ( $P$, $\mathrm{Ca}, \mathrm{Mg}$ and $\mathrm{K}$ ) and vitamins (Savage and Keenan, 1994). The multiple uses of the peanut make it an excellent cash crop for domestic markets as well as foreign trade. Peanut production process, from planting to storage, is affected by different types of constraints. Poor yields of peanut is mainly due to the biotic and abiotic constraints like erratic rainfall, low residual moisture, lack of high yielding adapted cultivars, damage by pest and diseases, poor agronomic practices, and limited use of inputs (Nageshwara Rao and Nigam, 2001). Therefore, it would be pertinent to assess the potential of new genotypes of peanut in in vitro conditions and new combination of PGRs for regeneration of whole plants. 
Triacontanol (TRIA), a long 30 carbon saturated primary alcohol, was discovered in 1933 as a natural components of epicuticulary waxes of Medicago sativa (Chibnall et al., 1933). The plant growth stimulating activities of TRIA (such as increase in dry weight, leaf area, and levels of reducing sugars, amino acids and soluble proteins) have been demonstrated by many researchers in many plants (Ries, 1985). Some authors have witnessed the role of TRIA in micropropagation of ornamental and other plants (Reddy et al., 2002; Tantos et al., 2001; Gururaj et al., 2007). However, very few information is available on the effect of this plant growth regulator in in vitro conditions in groundnut. Its effect in modulating antioxidant defense and biochemical aspects was also a part of investigation.

\section{MATERIALS AND METHODS}

Two cultivars of groundnut (Arachis hypogaea L.), M-13 (Spreading) and PBS24030 (Semi-spreading) were procured from Agricultural Research Station (ARS), Durgapura, Jaipur, Rajasthan, India. The seeds were washed with tap water for 10-15 min followed by immersion in liquid detergent solution labolene for $5 \mathrm{~min}$. After washing with distilled water, the seeds were again immersed with $70 \%$ ethanol for 3-5 min and rinsed with distilled water three to four times. Then the seeds were brought to the inoculation chamber and surface sterilized with $0.1 \% \mathrm{HgCl}_{2}$ for 8 min and rinsed with sterile distilled water for 3-4 times. Four to six surface sterilized seeds were germinated aseptically in a $250 \mathrm{ml}$ wide mouthed conical flask having sterilized wet cotton bed in dark. Based on our previous finding, cotyledonary node (CN) was excised from 10-12 days old seedling and used as explants (Verma et al., 2009). Such explants were cultured on MS medium (Murashige and Skoog, 1962) containing $3 \%(\mathrm{w} / \mathrm{v})$ sucrose and varying concentrations $\left(0.5,1.0\right.$ and $2.0 \mathrm{ml} \mathrm{L}^{-1}$ ) of Vipul (a commercial formulation of TRIA), procured from Godrej Agrovet Ltd., Sachin, India, alone and in combination with $\mathrm{BA}\left(3 \mathrm{mg} \mathrm{L}^{-1}\right)$. $\mathrm{CN}$ explant was inoculated and cultures were incubated at $24 \pm 2^{\circ} \mathrm{C}$ under 16 $\mathrm{h}$ exposures to white light of $80 \mu \mathrm{Em}^{-2} \mathrm{~s}^{-1}$ intensity provided by fluorescent tubes for 4-5 weeks for multiple shooting. Control set was devoid of any PGR. Shooting potential of this PGR was recorded after $40 \mathrm{DAl}$.

Biochemical and enzymatic estimations: Estimation of biochemical parameters and enzyme activity was carried in in vitro grown 25-30 days old leaves from lateral branches. Total chlorophyll content was estimated in leaves by the method of Coombs et al. (1985). The levels of chlorophyll were converted to $\mathrm{mg} \mathrm{g}^{-1} \mathrm{FW}$.

Hill reaction activity (HRA) was determined according to Cherry (1973). The HRA was expressed as $\mu \mathrm{g} \mathrm{g}^{-1} \mathrm{FW}$.

Catalase (CAT; EC 1.11.1.6) activity was calculated according to the modified method of Aebi (1984). One unit (U) of CAT activity was defined as the amount of enzyme catalyzing the decomposition of $1 \mu \mathrm{mol} \mathrm{H}_{2} \mathrm{O}_{2}$ per min at 240 $\mathrm{nm}$ calculated from the extinction coefficient of absorbance for $\mathrm{H}_{2} \mathrm{O}_{2}$ at $240 \mathrm{~nm}$ of $0.036 \mathrm{~cm}^{2} \mu \mathrm{mol}^{-1}$. The results were expressed as $\mathrm{U} \mathrm{g}^{-1} \mathrm{FW}$.

Ascorbate peroxidase (APX; EC 1.11.1.11) activity was determined according to the modified method of Zhu et al. (2004). One unit of APX activity was defined as the amount required to decompose $1 \mu \mathrm{mol}$ ascorbic acid oxidized $\mathrm{min}^{-1}$ calculated from the extinction coefficient of $2.6 \mathrm{mM}^{-1} \mathrm{~cm}^{-1}$. The results were expressed as $\mathrm{U} \mathrm{g}^{-1} \mathrm{FW}$.

Peroxidase (POX; 1.11.1.7) and Polyphenol oxidase (PPX; EC 1.14.18.1) activity was assayed adopting the method of Kar and Mishra (1976). One unit (U) of enzyme activity was defined as the amount of enzyme that caused an increase in absorbance at $420 \mathrm{~nm}$ of 0.01 per min. The enzyme activity was expressed in $\mathrm{U} \mathrm{g}^{-1} \mathrm{FW}$.

Malondialdehyde (MDA) content was estimated by following the method of Moshaty et al. (1993). The results were expressed in nmoles of MDA g ${ }^{-1} \mathrm{FW}$.

Total soluble sugars and proteins were estimated following the method of Clegg (1956) and Lowry et al. (1951), respectively.

Each growth experiment was conducted thrice taking three replicas of each treatment, under in vitro conditions. The data presented here are the means of three values \pm standard error (SE).

\section{RESULTS AND DISCUSSION}

Effect of TRIA on multiple shoot induction: In order to examine the role of TRIA, CN explants of both the cultivars were inoculated at different concentrations, 0.5, 1.0 and $2.0 \mathrm{ml} \mathrm{L}^{-1}$ was added alone and in combination with $\mathrm{BA}$ 
(3 $\mathrm{mg} \mathrm{L}^{-1}$ ) in the media (Table 1). The concentration of BA was selected on the basis of our recent studies (Verma et al., 2009). Shoot proliferation occurred as a consequence of the release of multiple shoots, axillary branches and shoot buds. With respect to the multiplication potential per explant, best response in $\mathrm{M}-13$ was noted on the medium containing $2.0 \mathrm{ml} \mathrm{L}^{-1}$ TRIA $(23.99 \pm 0.8)$ alone and in combination, the best response was observed on the medium containing $2.0 \mathrm{ml} \mathrm{L}^{-1}$ TRIA with BA, $3 \mathrm{mg} \mathrm{L}^{-1}$ $(31.11 \pm 2.0)$ over the control (Figure 1a).

In PBS24030, the number of shoots found to be increasing with the increasing concentrations of TRIA alone (Figure 1b). Best response was observed on the medium containing
$2.0 \mathrm{ml} \mathrm{L}^{-1}$ TRIA (21.88 \pm 0.2$)$ alone and in combination, on the medium containing $1.0 \mathrm{ml} \mathrm{L}^{-1}$ TRIA with $\mathrm{BA}, 3 \mathrm{mg} \mathrm{L}^{-1}$ $(30.77 \pm 0.6)$. Shooting response was observed in the control set also in both the genotypes which was devoid of any PGR. The extent of shoot elongation was found to be maximum with $0.5 \mathrm{ml} \mathrm{L}^{-1} \mathrm{TRIA}$ alone in both the cultivars. Flowering with roots were also observed on the medium containing $1.0 \mathrm{ml} \mathrm{L}^{-1}$ TRIA in PBS24030. Rhizogenesis was observed in the presence of TRIA alone. In M-13 roots were observed on MS media consisting of 0.5 and $2.0 \mathrm{ml} \mathrm{L}^{-1}$ TRIA (Figure 1c). Shoots failed to set roots, in the presence of BA. Well rooted plantlets were hardened (Figure 1d) and transferred to field condition, where they flowered and set viable seeds.

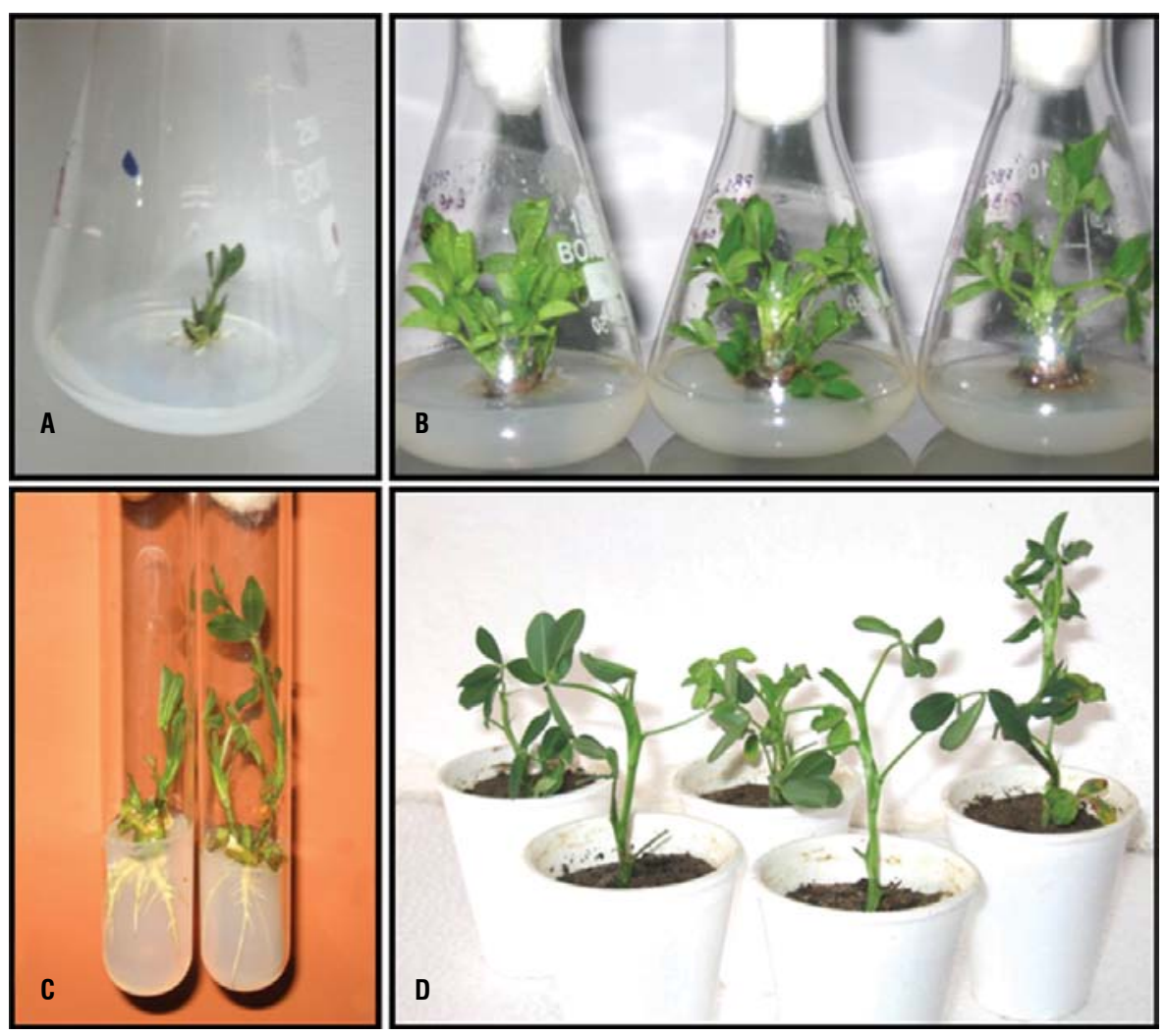

Figure 1. Response of Triacontanol (TRIA) alone and in combination with BA ( $\left.3 \mathrm{mg} \mathrm{L}^{-1}\right) 30 \mathrm{DAl}$, (a) cotyledonary node explant on MS basal medium and (b) in vitro grown CNs of PBS24030 on the MS basal medium containing $0.5,1.0$ and $2.0 \mathrm{ml} \mathrm{L}^{-1}$ TRIA alone, respectively from left to right (c) rooting in M-13 cultivar on MS basal medium supplemented with $0.5 \mathrm{ml} \mathrm{L}^{-1}$ and $2.0 \mathrm{ml} \mathrm{L}^{-1}$ TRIA (d) hardening of in vitro grown well rooted plantlets in thermocol pots of M-13. 
Table 1 Effect of Vipul (triacontanol, TRIA) with or without 6-Benzyl adenine $\left(\mathrm{BA}, 3 \mathrm{mg} \mathrm{L}^{-1}\right.$ ) on in vitro shoot multiplication (multiple shoots, axillary branches and shoot buds) per explant.

\begin{tabular}{cccc}
\hline \multirow{3}{*}{ S.No. } & Treatments $(\mathrm{ml}$ & \multicolumn{2}{c}{ Genotypes } \\
\cline { 3 - 4 } & $\left.\mathrm{L}^{-1}\right)$ & $\mathrm{M}-13$ & PBS24030 \\
\hline 1 & Control & $13.10 \pm 1.5$ & $2.31 \pm 0.5$ \\
2 & 0.5 TRIA & $19.33 \pm 1.4$ & $18.33 \pm 1.2$ \\
3 & 1.0 TRIA & $19.66 \pm 2.0$ & $16.88 \pm 1.5$ \\
4 & 2.0 TRIA & $23.99 \pm 0.8$ & $21.88 \pm 0.2$ \\
5 & BA & $27.77 \pm 3.3$ & $25.55 \pm 1.9$ \\
6 & BA + 0.5 TRIA & $26.66 \pm 1.5$ & $26.22 \pm 1.7$ \\
7 & BA + 1.0 TRIA & $29.11 \pm 3.1$ & $30.77 \pm 0.6$ \\
8 & BA + 2.0 TRIA & $31.11 \pm 2.0$ & $28.11 \pm 1.6$ \\
\hline
\end{tabular}

Values are the mean of three replicates \pm SE

The effectiveness of TRIA in shoot proliferation has been reported earlier for several other plant species e.g. Melissa officinalis (Tentos et al., 1999) Bupleurum fruticosum (Frantanele et al,. 2002), Malus domestica (Tentos et al., 2001), lemon grass (Knight and Mithchell, 1987), Capsicum frutescens (Reddy et al., 2002), etc. Hangarter and Ries (1978) suggested that the increased growth caused by TRIA is not simply due to water uptake and cell enlargement but rather due to an increase in cell number. Grzegorczyk and Wysokinska (2008) reported that TRIA when added to the liquid media along with BA and IAA stimulated shoots multiplication at all concentration tested $\left(5,10\right.$ and $\left.15 \mu \mathrm{g} \mathrm{L}^{-1}\right)$ in sage. Low concentrations of TRIA may be biologically active because of the sensitivity of whole explants to extremely low doses of TRIA (Malabadi et al,. 2005).

Effect of TRIA on total chlorophyll content and Hill reaction activity (HRA): The chlorophyll content increased progressively with an increase in the concentration of TRIA alone or in combination with BA in both the cultivars (Table 2). The effect was similar in both the cultivars. The highest concentration of TRIA alone $\left(2.0 \mathrm{ml} \mathrm{L}^{-1}\right)$ significantly enhanced the total chlorophyll in M-13 and PBS24030 to $0.155 \pm 0.007$ and $0.156 \pm 0.01 \mathrm{mg} \mathrm{g}^{-1} \mathrm{FW}$ respectively at 25 DAl. This corresponded to an increase of $82.4 \%$ and $81.4 \%$ over the control respectively. While in the presence of TRIA $(2.0 \mathrm{ml}$ $\left.\mathrm{L}^{-1}\right)$ along with $\mathrm{BA}\left(3 \mathrm{mg} \mathrm{L}^{-1}\right)$, the total chlorophyll content in $\mathrm{M}-13$ and PBS24030 was found to be $0.223 \pm 0.04$ and $0.187 \pm 0.011 \mathrm{mg} \mathrm{g}^{-1} \mathrm{FW}$ respectively which was more than twice compared to the control. In both the cultivars HRA was found to be influenced by TRIA being most pronounced at 1.0 $\mathrm{ml} \mathrm{L}^{-1}$ TRIA alone, although there were genotypic differences (Table 2). The highest HRA in the presence of TRIA $(1.0 \mathrm{ml}$ $\mathrm{L}^{-1}$ ) alone in $\mathrm{M}-13$ and PBS24030 was 32.6 and 26.2 folds respectively as compared to their respective controls.

Growth promoting effects of TRIA have been reported in different plants (Malik et al., 1990; Naeem et al., 2009; Ries, 1985; Shripathi, 1996). This could presumably be attributed to an increase in the number and size of chloroplasts as revealed by Chen et al. (2003), Ivanov and Angelov (1997) and Muthuchelian et al. (2003) which in turn might be increasing the HRA. Setia et al. (1996) studied the influence of aliphatic alcohols on growth and development in fruits of Brassica juncea (L.) and found increased HRA in the chloroplasts. Foliar spray of TRIA enhanced chlorophyll content in oat and rice (Bhalla, 1981), rape leaves (Zhou et al., 1994), soybean plants (Krishnan and Ranjitha Kumari, 2008) and wheat plants (Perveen et al., 2010).

Effect of TRIA on the levels of total soluble carbohydrates and protein: Total soluble carbohydrate content was found to be significantly high in TRIA treated cultures as compared to control (Table 2). In both the cultivars, the content was kept on increasing with the increasing concentrations of TRIA alone as well as in combination. The rise in the same is more pronounced in M-13 cultivar as compared to PBS24030. A continuous increase in the total protein content was observed in all the TRIA treated cultures whether alone or in combination with BA than the control in both the cultivars (Table 2). Increase in $\mathrm{M}-13$ genotype was more as compared to PBS24030. Highest content of soluble protein was observed at $2.0 \mathrm{ml} \mathrm{L}^{-1}$ TRIA with $\mathrm{BA}\left(3 \mathrm{mg} \mathrm{L}^{-1}\right)$ in both the cultivars. These results coincide with those obtained by Knowles and Ries (1981), Kumaravelu et al. (2000), Muthuchelian et al. (2003) and Ries and Houtz (1983) for various crops. In the present investigation, the increase in soluble protein content in both the genotypes is likely to improve growth and hence yield of the crop as reported earlier by Ries and Wert (1982).

\section{Influence of TRIA on antioxidant enzyme activities}

Effect of TRIA on Catalase (CAT) and ascorbate peroxidase (APX) activity: The data set in Table 3 indicated that TRIA caused an enhancement in the activity of CAT and APX and its effect was concentration dependent and influenced by the genotypic differences. In M-13, maximum 
CAT activity was seen at $0.5 \mathrm{ml} \mathrm{L}^{-1}$ of TRIA alone which was $\sim 21$ fold higher than the control. With further increase in the concentration of TRIA, the activity declined. However, application of $\mathrm{BA}\left(3 \mathrm{mg} \mathrm{L}^{-1}\right)$ alone showed 1.56 folds higher CAT activity than TRIA at $1.0 \mathrm{ml} \mathrm{L}^{-1}$ with BA. In PBS24030 cultivar, the CAT activity increased 2 folds than the control at $0.5 \mathrm{ml} \mathrm{L}^{-1}$. A continuous increase in APX activity was seen in TRIA treated cultures as compared to control. In M-13 cultivar, the activity of APX increased 4.5 folds over the control at 2.0 $\mathrm{ml} \mathrm{L}^{-1}$ alone. Similar consistent results were observed in PBS24030 cultivar. Maximum activity was observed at $2.0 \mathrm{ml}$
$\mathrm{L}^{-1}$ TRIA alone and in combination with BA corresponding to 11 and $\sim 20$ folds enhancement, respectively over the control.

Our findings are in agreement with Sankar et al. (2007) who reported the effect of paclobutrazol, an aliphatic alcohol like TRIA, on antioxidants and free radical scavenging enzymes in Arachis hypogaea L. and showed an increase in CAT and APX activity. APX could be responsible for the fine modulation of ROS for signaling and its increased activity would lead to establish a balance between ROS production and its scavenging (Gomes-Junior et al., 2006).

Table 2. Effect of Vipul (triacontanol, TRIA) on the biochemical parameters in the in vitro grown leaves sampled from 25 days old culture (BR 1-C), treated with different concentrations of TRIA alone (ml L-1) or in combination with $B A\left(3 \mathrm{mg} \mathrm{L}^{-1}\right)$.

\begin{tabular}{|c|c|c|c|c|c|c|c|c|c|}
\hline \multirow{3}{*}{ S. No. } & \multirow{3}{*}{$\begin{array}{l}\text { Treatments } \\
\left(\mathrm{ml} \mathrm{L}^{-1}\right)\end{array}$} & \multicolumn{8}{|c|}{ Biochemical parameters } \\
\hline & & \multicolumn{2}{|c|}{$\begin{array}{l}\text { Chlorophyll Content } \\
\qquad\left(\mathrm{mg} \mathrm{g}^{-1} \mathrm{FW}\right)\end{array}$} & \multicolumn{2}{|c|}{$\begin{array}{l}\text { Hill Reaction Activity } \\
\qquad\left(\mu \mathrm{g} \mathrm{g}{ }^{-1} \mathrm{FW}\right)\end{array}$} & \multicolumn{2}{|c|}{$\begin{array}{l}\text { Total Soluble Carbohydrates } \\
\qquad\left(\mathrm{mg} \mathrm{g}^{-1} \mathrm{FW}\right) \\
\end{array}$} & \multicolumn{2}{|c|}{$\begin{array}{l}\text { Total Soluble Proteins } \\
\qquad\left(\mathrm{mg} \mathrm{g}^{-1} \mathrm{FW}\right)\end{array}$} \\
\hline & & $M-13$ & PBS24030 & $M-13$ & PBS24030 & $M-13$ & PBS24030 & $M-13$ & PBS24030 \\
\hline 1 & Control & $0.085 \pm 0.001$ & $0.086 \pm 0.015$ & $12.22 \pm 0.9$ & $10.88 \pm 0.35$ & $0.438 \pm 0.6$ & $1.175 \pm 0.03$ & $0.144 \pm 0.01$ & $0.162 \pm 0.01$ \\
\hline 2 & 0.5 TRIA & $0.115 \pm 0.005$ & $0.115 \pm 0.002$ & $77.4 \pm 0.8$ & $30.97 \pm 0.68$ & $0.568 \pm 0.5$ & $2.178 \pm 0.24$ & $0.194 \pm 0.01$ & $0.189 \pm 0.01$ \\
\hline 3 & 1.0 TRIA & $0.126 \pm 0.007$ & $0.131 \pm 0.005$ & $398.03 \pm 1.1$ & $284.96 \pm 1.78$ & $1.959 \pm 0.6$ & $4.451 \pm 0.3$ & $0.210 \pm 0.02$ & $0.228 \pm 0.02$ \\
\hline 4 & 2.0 TRIA & $0.155 \pm 0.007$ & $0.156 \pm 0.01$ & $114 \pm 1.9$ & $195.1 \pm 1.31$ & $3.029 \pm 0.8$ & $4.953 \pm 0.2$ & $0.230 \pm 0.01$ & $0.252 \pm 0.01$ \\
\hline 5 & BA & $0.166 \pm 0.004$ & $0.185 \pm 0.011$ & $485.79 \pm 2.2$ & $417.88 \pm 1.44$ & $8.237 \pm 0.1$ & $5.658 \pm 0.18$ & $0.290 \pm 0.01$ & $0.280 \pm 0.01$ \\
\hline 6 & $\mathrm{BA}+0.5 \mathrm{TRIA}$ & $0.201 \pm 0.003$ & $0.199 \pm 0.005$ & $348.03 \pm 1.2$ & $123.63 \pm 1.14$ & $7.178 \pm 0.1$ & $6.487 \pm 0.04$ & $0.357 \pm 0.02$ & $0.260 \pm 0.02$ \\
\hline 7 & $\mathrm{BA}+1.0$ TRIA & $0.205 \pm 0.013$ & $0.204 \pm 0.022$ & $587.1 \pm 2.1$ & $494.62 \pm 1.65$ & $7.738 \pm 0.1$ & $7.632 \pm 0.24$ & $0.428 \pm 0.03$ & $0.355 \pm 0.02$ \\
\hline 8 & $\mathrm{BA}+2.0 \mathrm{TRIA}$ & $0.223 \pm 0.04$ & $0.187 \pm 0.011$ & $404.38 \pm 2.3$ & $676.24 \pm 1.46$ & $15.217 \pm 2.3$ & $7.918 \pm 0.3$ & $0.440 \pm 0.03$ & $0.382 \pm 0.01$ \\
\hline
\end{tabular}

Values are the mean of three replicates $\pm \mathrm{SE}$.

Table 3. Effect of Vipul (triacontanol, TRIA) on the antioxidant enzyme activities in the in vitro grown leaves sampled from 25 days old culture (BR 1-C), treated with different concentrations of TRIA alone $\left(\mathrm{ml} \mathrm{L}^{-1}\right)$ or in combination with BA $\left(3 \mathrm{mg} \mathrm{L}^{-1}\right)$.

\begin{tabular}{|c|c|c|c|c|c|c|c|c|c|}
\hline \multirow{3}{*}{ S.No. } & \multirow{3}{*}{$\begin{array}{l}\text { Treatments } \\
\left(\mathrm{ml} \mathrm{L}^{-1}\right)\end{array}$} & \multicolumn{8}{|c|}{ Enzyme activities } \\
\hline & & \multicolumn{2}{|c|}{$\begin{array}{c}\text { CAT } \\
\left(\mathrm{U} \mathrm{g}^{-1} \mathrm{FW}\right)\end{array}$} & \multicolumn{2}{|c|}{$\begin{array}{c}\text { POX } \\
\left(\mathrm{U} \mathrm{g}^{-1} \mathrm{FW}\right) \\
\end{array}$} & \multicolumn{2}{|c|}{$\begin{array}{c}\text { PPX } \\
\left(\mathrm{U} \mathrm{g}^{-1} \mathrm{FW}\right)\end{array}$} & \multicolumn{2}{|c|}{$\begin{array}{c}\text { APX } \\
\left(\mathrm{U} \cdot \mathrm{g}^{-1} \mathrm{FW}\right)\end{array}$} \\
\hline & & $\mathrm{M}-13$ & PBS24030 & $M-13$ & PBS24030 & $M-13$ & PBS24030 & $M-13$ & PBS24030 \\
\hline 1 & Control & $7.59 \pm 0.6$ & $50.52 \pm 1.4$ & $18 \pm 0.03$ & $22 \pm 0.01$ & $24 \pm 0.01$ & $27 \pm 0.02$ & $1.55 \pm 0.2$ & $0.83 \pm 0.02$ \\
\hline 2 & 0.5 TRIA & $155.96 \pm 0.8$ & $67.95 \pm 0.5$ & $39 \pm 0.01$ & $34 \pm 0.02$ & $34 \pm 0.02$ & $35 \pm 0.01$ & $5.07 \pm 0.01$ & $5.85 \pm 0.07$ \\
\hline 3 & 1.0 TRIA & $87.69 \pm 1.8$ & $133.72 \pm 1.2$ & $44 \pm 0.02$ & $47 \pm 0.01$ & $39 \pm 0.01$ & $39 \pm 0.008$ & $5.85 \pm 0.04$ & $8.36 \pm 0.25$ \\
\hline 4 & 2.0 TRIA & $85.74 \pm 0.3$ & $75.26 \pm 0.6$ & $45 \pm 0.009$ & $50 \pm 0.006$ & $52 \pm 0.01$ & $43 \pm 0.01$ & $7.08 \pm 0.3$ & $9.13 \pm 0.22$ \\
\hline 5 & BA & $356.25 \pm 0.8$ & $170.91 \pm 0.9$ & $51 \pm 0.01$ & $41 \pm 0.021$ & $39 \pm 0.01$ & $37 \pm 0.02$ & $6.22 \pm 0.01$ & $10.25 \pm 0.01$ \\
\hline 6 & $\mathrm{BA}+0.5 \mathrm{TRIA}$ & $67.33 \pm 0.7$ & $86.26 \pm 1.4$ & $54 \pm 0.01$ & $57 \pm 0.01$ & $42 \pm 0.03$ & $40 \pm 0.01$ & $8.95 \pm 0.1$ & $13.99 \pm 0.08$ \\
\hline 7 & $\mathrm{BA}+1.0 \mathrm{TRIA}$ & $227.96 \pm 1.8$ & $87.6 \pm 0.8$ & $57 \pm 0.03$ & $59 \pm 0.001$ & $61 \pm 0.01$ & $47 \pm 0.04$ & $10.83 \pm 0.6$ & $14.03 \pm 0.69$ \\
\hline 8 & $\mathrm{BA}+2.0 \mathrm{TRIA}$ & $41.8 \pm 0.3$ & $81.7 \pm 0.3$ & $41 \pm 0.01$ & $64 \pm 0.02$ & $48 \pm 0.03$ & $50 \pm 0.01$ & $17.61 \pm 0.3$ & $16.02 \pm 0.63$ \\
\hline
\end{tabular}

Values are the mean of three replicates $\pm \mathrm{SE}$ 
Effect of TRIA on peroxidase (POX) and polyphenol oxidase (PPX) activity: POX activity (expressed in absorbance values) varied between control and treated plants. In both the cultivars, POX activity found to be increasing with the increasing concentrations of TRIA ( $\mathrm{ml} \mathrm{L}^{-1}$ ) as compared to control. Presence of $B A$ augmented the activity of the enzyme. However, POX activity in PBS24030 was higher than M-13. TRIA treated cultures showed enhanced PPX activity in both the groundnut cultivars (Table 3). In M-13, PPX activity was found to be increased with the increasing concentration of TRIA alone. However, when TRIA was added with BA, higher PPX activity was noted at $1.0 \mathrm{ml} \mathrm{L}^{-1}$ TRIA in combination with BA. On the other hand, PPX activity increased in PBS24030 with all concentrations of TRIA ( $\left.\mathrm{ml} \mathrm{L}^{-1}\right)$ whether alone or in combination with BA.

Henry and Gordon (1980) reported an increase in POX activity in pea plants treated with TRIA as compared to untreated controls. Naeem et al. (2009) also reported that TRIA stimulated PPX activity along with other enzymes in hyacinth bean (Lablab purpureus L.), hence causing improved plant defense system, nitrogen fixation, photosynthesis and better crop productivity.

Effect of TRIA on malondialdehyde (MDA) content: In the present investigation we have demonstrated that TRIA, a naturally occurring aliphatic alcohol could affect MDA levels (measure of lipid peroxidation) (Table 4). The amount of MDA was much higher in controls than the TRIA treated cultures in both the cultivars. The content of MDA decreased with the increased concentrations of TRIA both alone as well as in combination in both the cultivars.

Table 4. Lipid peroxidation (MDA) (nmoles of MDA $\mathrm{g}^{-1} \mathrm{FW}$ ) in the in vitro grown leaves sampled from 25 days old culture (BR $1-C$ ) treated with different concentrations of TRIA alone ( $\left.\mathrm{ml} \mathrm{L}^{-1}\right)$ or with $B A\left(3 \mathrm{mg} \mathrm{L}^{-1}\right)$.

\begin{tabular}{cccc}
\hline \multirow{2}{*}{ S.No. } & Treatments $\left(\mathrm{ml} \mathrm{L}^{-1}\right)$ & \multicolumn{2}{c}{ Genotypes } \\
\cline { 3 - 4 } & & $\mathrm{M}-13$ & PBS24030 \\
\hline 1 & Control & $47 \pm 0.003$ & $39 \pm 0.001$ \\
2 & 0.5 TRIA & $34 \pm 0.003$ & $27 \pm 0.001$ \\
3 & 1.0 TRIA & $27 \pm 0.003$ & $21 \pm 0.002$ \\
4 & 2.0 TRIA & $12 \pm 0.004$ & $15 \pm 0.004$ \\
5 & BA & $26 \pm 0.001$ & $22 \pm 0.005$ \\
6 & BA + 0.5 TRIA & $31 \pm 0.006$ & $21 \pm 0.002$ \\
7 & BA + 1.0 TRIA & $11 \pm 0.004$ & $17 \pm 0.001$ \\
8 & BA + 2.0 TRIA & $14 \pm 0.003$ & $20 \pm 0.004$ \\
\hline
\end{tabular}

Values are the mean of three replicates \pm SE
Ramanarayan et al (2000) and Zhou et al (1994) reported that TRIA significantly reduced lipid peroxidation in isolated chloroplasts of spinach (Spinacea oleracea L.) and in rape leaves. Decrease in the MDA content in both the cultivars might be due to a decrease in the polyunsaturated fatty acid concentration relative to saturated fatty acids, which was also been reported in cucumber (Kramer et al., 1991). Thus protects plant cells against oxidative damage by inducing antioxidant defense.

\section{CONCLUSION}

The data presented in this paper have demonstrated that TRIA can be effectively used for the direct organogenesis from the CN explant in both the cultivars. Experimental evidences indicated that in vitro effect of TRIA was involved in the alleviation of not only antioxidant capacity but also biochemical parameters. However, there are some differences in the responsive behaviors of the two groundnut cultivars in the presence of TRIA which may be attributed to the genetic differences. Our results clearly indicate that TRIA is a potent plant growth regulator in various aspects.

\section{REFERENCES}

Aebi H (1984) Catalase in vitro. In: Methods Enzymol. 105: Packer L (Editor) pp 121-6. Academic Press New York.

Bhalla PR (1981) In Proceedings of $8^{\text {th }}$ Ann Plant Growth Regulator Soc Florida 184.

Chen X, Yuan H, Chen R, Zhu L, He G (2003) Biochemical and photochemical changes in response to triacontanol in rice (Oryza sativa L). Plant Growth Regul. 40: 249-256.

Cheng M, His DCH, Phillips GC (1992) In vitro regeneration of Valencia-type peanut (Arachis hypogaea L.) from cultured petioles, epicotyl sections and other seedling explants. Peanut Sci 19: 82-87.

Cherry JH (1973) Molecular biology of plants, a text manual. pp 1-204 Colombia University Press, New York, USA.

Chibnall AC, Williams Latner AL, Pipes AH (1933) The isolation of n-triacontanol from lucerne wax. Biochem J. 27: 1885-1888.

Clegg KM (1956) Application of Anthrone reagent to the estimation of starch in cereals. J Sci Food Agrilcul 7: 40-44.

Coombs J, Hall DO, Long SP, Scurlock JMO (1985) Techniques in bioproductivity and photosynthesis $\left(2^{\text {nd }} e d\right)$. p. 223-234. Paragamon Intl., Oxford.

Frantanele D, Giamperi L, Ricci D, Rocchi MBL (2002) Micropropagation of Bupleurum fruticosum: The effect of triacontanol. Plant Cell Tissue Organ Cult. 69: 135-140.

Gomes-Junior RA, Moldes CA, Delite FS, Pompeu GB, Gratao PL, Mazzafera P, Lea PJ, Azevedo RA (2006) Antioxidant metabolism of coffee cell suspension cultures in response of cadmium. Chemosphere 65: 1330-1337. 
Grzegorczyk I, Wysokinskam H (2008) Liquid shoot culture of Salvia officinalis $L$. for micropropagation and production of antioxidant compounds: effect of triacontanol. Acta Soc. Botanicorum Poloniae 73: 99-104.

Hangarter R, Ries S (1978) Effect of triacontanol on plant cell cultures in vitro. Plant Physiol. 61: 855-857.

Henry EW, Gordon CJ (1980) The Effect of Triacontanol on Peroxidase, IAA, and Plant Growth in Pisum sativum var.'Alaska' and 'Little Marvel'. J Exp Bot 31(5): 1297-1303.

Ivanov AG, Angelov MN (1997) Photosynthesis response to triacontanol correlates with increased dynamics of mesophyll protoplast and chloroplast membranes. Plant Growth Regul. 21: 145-152.

Kar M, Mishra D (1976) Catalase, peroxidase and polyphenol oxidase activities during rice leaf senescence. Plant Physiol 57: 315-319.

Knight SL, Mitchell CA (1987) Stimulation productivity of hydroponic lettuce in controlled environments with triacontanol. Hort Sci 22: 1307-1309.

Knowles NR, Ries SK (1981) Rapid growth and apparent total nitrogen increases in rice and corn plants following application of triacontanol. Plant Physiol. 68: 1279-1284.

Kramer GF, Norman HA, Krizek DT, Mirecki RM (1991) Influence of UV-B radiation on polyamines, lipid peroxidation and membrane lipids in cucumber. Phytochem 30: 2101-2108.

Krishnan RR, Ranjitha Kumari BD (2008) Effect of n-triacontanol on the growth of salt stressed soybean plants. J Biosci 19(2): 53-62.

Kumaravelu G, Livingstone VD, Ramanujam MP (2000) Triacontanol-induced changes in the growth, photosynthetic pigments, cell metabolites, flowering and yield of green gram. Biol. Plant 43: 287-290.

Lowry OH, Rosenbrough HJ, Farr AL, Randall RJ (1951) Protein measurement with Folin-Phenol reagent. J Biol Chem 193: 265-275.

Malabadi RB, Mulgund GS, Nataraja K (2005) Efficient regeneration of Vanda coeruleu an endangered orchid using thidiazuron. Plant Cell Tissue Organ Cult. 76: 289-293.

Malik CP, Singh P, Kaur S, Malik S, Parmar U, Grewal M, Bhatia DS (1990) Modification of leaf photosynthesis by foliar application of aliphatic alcohols. J Agr Crop Sci 165: 198-201.

Moshaty EFIB, Pike SM, Novacky AJ, Sehgal OP (1993) Lipid peroxidation and superoxide production in cowpea (Vigna unguiculata) leaves infected with tobacco ring spot virus or southern bean mosaic virus. Physiol Mol Plant Pathol 43: 109-119.

Murashige T, Skoog F (1962) A Revised Medium for Rapid Growth and Bio Assays with Tobacco Tissue Cultures. Physiol Plant 15: 473-497.

Muthuchelian K, Velayutham M, Nedunchezhian N (2003) Ameliorating effect of triacontanol on acidic mist-treated Erythrina variegata seedlings. Changes in growth and photosynthetic activities. Plant Sci, 165: 1253-1257.

Nageshwara Rao RC, Nigam SN (2001) Genetic options for drought management for groundnut. In Saxena NP (ed) Management of agricultural drought: Agronomic and Genetic Options. Oxford and IBH, New Delhi, 123141.
Naeem M, Khan MM, Moinuddin A, Manzer Siddiqui H (2009) Triacontanol stimulates nitrogen-fixation, enzyme activities, photosynthesis, crop productivity and quality of hyacinth bean (Lablab purpureus L.). Scientia Horticulturae 121(4): 389-396.

Perveen S, Shahbaz M, Ashraf M (2010) Regulation in gas exchange and quantum yield of photosystem II (PSII) in salt-stressed and non-stressed wheat plants raised from seed treated with triacontanol Pak. J. Bot. 42(5): 3073-3081.

Ramanarayan K, Bhat A, Shripathi V, Sivakumar Swamy G, Sankara Rao K (2000) Triacontanol inhibits both enzymatic and nonenzymatic lipid peroxidation. Phytochem 55: 59-66.

Reddy BO, Giridhar P, Ravishankar GA (2002) The effect of triacontanol on the micropropagation of Capsicum frutiscens and Decalepis hamiltonii W\&A. Plant Cell Tissue Organ Cult. 71: 253-258.

Ries S, Houtz R (1983) Triacontanol as a plant growth regulator. Hort. Sci. 18: $654-662$

Ries SK, Wert VF (1982) Rapid effects of triacontanol in vivo and in vitro. J. Plant Growth Regul. 1: 117-127.

Ries SK (1985) Regulation of plant growth with triacontanol. CRC Crit Rev Plant Sci 2(3): 239-285.

Sankar B, Jaleel AC, Manivannan P, Kishorekumar A, Somasundaram R, Panneerselvam $R$ (2007) Effect of paclobutrazol on water stress amelioration through antioxidants and free radical scavenging enzymes in Arachis hypogaea L. Colloids and Surfaces B. Biointerfaces 60(2): 229-235.

Savage GP, Keenan Jl (1994) The composition and nutritive value of Groundnut kernels In Smart J (ed). The Groundnut crop: Scientific Basis for Improvement London Chapman and Hall, 173-213.

Setia RC, Kaur P, Setia N, Anuradha (1996) Influence of paclobutrazol on growth and development of fruit in Brassica juncea (L.) Czern Coss. Plant Growth Regul 20(3): 307-316.

Shripathi V (1996) Growth regulator induced changes in physicochemica properties of lipids in plants. Ph.D. Thesis. Karnatak University Dharwad.

Tantos A, Meszaros A, Kissimon J, Horvath G, Farkas T (1999) The effect of triacontanol on the micropropagation of balm, Melissa officinalis. Plant Cell Rep. 19: 88-91.

Tantos A, Meszaros A, Farkas T, Szalai J, Horvath G (2001) Triacontanol supported the micropropagation of woody plants. Plant Cell Rep. 20: 16-21.

Verma A, Malik CP, Gupta VK, Sinsinwar YK (2009) Response of groundnut varieties to plant growth regulator (BAP) to induce direct organogenesis. World J Agricult Sci 5(3): 313-317.

Zhou W, Tao S, Zhao D (1994) Physiologic regulation of mixtalol in rape senescence and its yield. J Plant Growth Regul 14(1): 37-40.

Zhu YZ, Huang SH, Tan BKH, Sun J, Whiteman M, Zhu YC (2004) Antioxidants in Chinese herbal medicines: a biochemical perspective. Natl. Prod. Rep. 21: 478-489. 